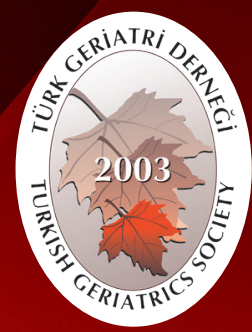

Turkish Journal of Geriatrics DOI: $10.31086 /$ tigeri.2018.60 2018;21 (4):544-549

- Aylin Hande GÖKÇE

- Feridun Suat GÖKÇE

CORRESPONDANCE

Aylin Hande GÖKÇE

Balıkı Rum Hospital, General Surgery,

istanbul, Turkey

Phone: 02125471600

e-mail: ahgokce79@hotmail.com

Received: 28/05/2018

Accepted: 07/12/2018

Balıkı Rum Hospital, General Surgery, İstanbul, Turkey
RESEARCH

\section{SAFETY AND COMPLICATION OF PERCUTANEOUS ENDOSCOPIC GASTROSTOMY BY AGE GROUPS: A RETROSPECTIVE CLINICAL TRIAL}

\section{Abstract}

Introduction: This study aimed at conducting comparisons across age groups on the safety of Percutaneous Endoscopic Gastrostomy (PEG) procedure and the rates of complications when used to resolve dysphagia and other oral intake problems which are increasing in prevalence in line with population ageing.

Materials and Method: Data from patients aged 65 years and over, who underwent a PEG procedure in our clinic between 2012-2017 were retrospectively reviewed. Age and sex of study subjects and the reason for performing PEG procedure and complications were assessed. Patients were assigned into two age groups: Group1 included patients aged from 65 to 85 years and Group2 aged 85 years and over.

Results: 76 out of 182 patients were in group 1 and 106 were in group 2. There were 139 female, 43 male patients. 21(11.2\%) patients developed PEG related-complications and there was PEG revision in seven (3.8\%) patients. The most common complications were peristomal infections in the Group 1 and peristomal infections and formulation leakage around the PEG tube site, in the Group 2. No statistically significant intergroup differences were found in complication rates and PEG revision rates $(p=0.349$ and $p=0.701$, respectively). Mortality occurred in none of the groups 2 at the end 30-day follow up during the study.

Conclusion: In patients who underwent a PEG procedure, no differences were found between patients aged 65 to 85 years and patients aged 86 years and over in terms of complication rates and PEG revision rates. We believe that PEG is a safe procedure with low complication rates, when performed following a detailed assessment and thorough preparations.

Keywords: Gastrostomy; Deglutition disorders; Aged; Malnutrition

ARAŞTIRMA

\section{PERKÜTAN ENDOSKOPIK GASTROSTOMI UYGULAMASININ GÜVENILIRLIĞi VE KOMPLIKASYONLARININ YAŞ GRUPLARINA GÖRE KARŞILAŞTIRILMASI: RETROSPEKTIF KLINIK ÇALIŞMA}

$\ddot{\mathrm{O}}_{z}$

Giriş: Yaşlı nüfusun artmasıyla sıkça görülmeye başlanan yutma güçlüğü ve diğer oral beslenme problemlerinin çözümünde Perkütan Endoskopik Gastrostomi (PEG) işleminin güvenirliliği ve komplikasyon yüzdelerinin yaş gruplarına göre karşılaştııılması amaçlanmıştır.

Gereç ve Yöntem: 2012 ile 2017 tarihleri arasında PEG uygulanan 65 yaş ve üstü hastaların verileri retrospektif olarak incelendi. Hastaların yaş, cinsiyet, PEG açılması nedeni ve komplikasyonları değerlendirildi. Hastalar Grup 1; 65-85 yaş, Grup 2; 86 ve üzeri yaş olmak üzere ikiye ayrıldı.

Bulgular: Çalışmaya alınan 182 hastanın 76 sı grup 1, 106 sı grup 2 idi. Hastaların 139'u kadın 43'ü erkekti. Toplam 21 hastada (\%11.2) komplikasyon görüldü ve 7 hastada (\%3.8) PEG değişimi yapıldı. En sık saptanan komplikasyon grup 1 de peristomal enfeksiyon, grup 2 de ise peristomal enfeksiyon ve PEG tüpünün yanından mama kaçağıydı. İki grup arasında komplikasyon görülmesi ve PEG revizyonu açısından istatistiksel fark saptanmadı (sırasıyla $p=0.349, p=0.701)$. Çalışmada iki grupta da 30 gün sonunda mortalite görülmedi.

Sonuç: 65-85 yaş arası ve 86 yaş üzeri PEG uygulanan olgularda komplikasyon ve PEG revizyonu açısından fark saptanmadı. Geriatrik hasta grubunda detaylı değerlendirme ve hazırlık yapıldıktan sonra PEG uygulaması yapılmasının düşük komplikasyon oranı ile güvenle uygulanabilecek bir işlem olduğunu düşünmekteyiz.

Anahtar sözcükler: Gastrostomi; Disfaji; Geriatri; Malnutrisyon 


\section{INTRODUCTION}

For patients requiring long-term tube feeding, enteral nutrition has several advantages over parenteral nutrition, including lower cost, easier and comfortable administration, intestinal flora protection and mucosal atrophy prevention as well as lower rates of bacterial translocation. The long-term use of nasogastric, nasoduodenal or nasojejunal tubes in patients requiring enteral nutrition can cause nasopharyngeal discomfort, nasal erosion, acute otitis media, acute sinusitis, pharyngeal ulceration, esophagitis, esophageal ulceration, oesophageal varice rupture and gastric erosion and ulceration (1). Therefore, if long-term enteral tube nutrition is planned, clinicians should consider switching to percutaneous endoscopic gastrostomy (PEG) feeding at an early stage. PEG, first described by Gauder et al. in 1980, is a technique for delivering nutrition, fluids and/or medications directly into the stomach, bypassing the mouth and esophagus, in patients who have impaired oral intake due to various reasons but have an intact gastrointestinal tract (2). PEG is often used in place of conventional gastrostomy since it is simple, has a low complication rate and is relatively inexpensive $(3,4)$. Three techniques are commonly used for PEG tube placement: the pull technique, push technique and introducer technique. The pull technique is the first choice (5).

A literature review revealed that neurogenic dysphagia was the most common indication for placing a feeding tube using PEG $(6,7)$. In addition, PEG is indicated in patients with conditions leading to malnutrition, such as metabolic diseases, cardiac disease, cystic fibrosis, trauma, malignancies and oropharyngeal anatomical abnormalities $(4,8)$. PEG tube placement is contraindicated in patients with severe esophageal strictures or diffuse ascites accumulation in the abdominal cavity, morbid obesity, uncontrollable coagulation disorders, previous stomach surgeries, severe hiatal hernia and advanced cancers (9).
In this study, we aimed at conducting comparisons across geriatric age groups on the safety of Percutaneous Endoscopic Gastrostomy (PEG) procedures and the rates of complications associated with Percutaneous Endoscopic Gastrostomy (PEG) used to resolve dysphagia and other oral intake problems which are increasing in prevalence in line with population ageing.

\section{MATERIALS AND METHOD}

The present study was conducted according to the recommendations of the Declaration of Helsinki on Biomedical Research Involving Human Subjects. This retrospective clinical study was performed at our hospital, Department of General Surgery after obtaining approval of the Local Ethics Committee (KAEK-50-1269). Patients' relatives provided informed consents. We retrospectively reviewed the medical records of elderly patients who underwent PEG at our hospital between 2012 and 2017. The inclusion criterion was to be aged 65 years and over. Age and sex of study subjects and the reason for performing a PEG procedure, complications associated with PEG and time to death were recorded. Patients were divided into two groups, the Group I included patients aged between 65 and 85 years and the Group 2 included patients aged 86 years and older. The two groups were compared to each other in complication rates.

\section{Procedure}

The PEG procedures were performed by two endoscopists (AHG, FG) using the same commercial PEG kit. Each patient received antibiotic prophylaxis with cefazolin sodium $1 \mathrm{~h}$ before the procedure, and a $\mathrm{H}_{2}$ receptor blocker was intravenously administered for the first 3 days later. Patients were given water and formula through the PEG tube 24 $\mathrm{h}$ and $48 \mathrm{~h}$ after the procedure, respectively. In this study, the pull technique was used for PEG tube placement in all patients. 


\section{Statistical analysis}

Data were analyzed using the SPSS (Statistical Package for Social Sciences, Windows Version 22.0) software. In addition to descriptive statistics (mean, standard deviation), one-way analysis of variance was used for intergroup comparisons and the chi-square test was used for the comparisons of quantitative data. A p value of $<0.05$ was considered significant.

\section{RESULTS}

From 2012 to 2017, 191 patients underwent PEG. Of these patients, 107 had dementia, 44 had cerebrovascular disorders, 26 had hypoxic brain damage, six had head or neck cancers and eight had other disorders. Nine patients who not meet the eligibility criterion of age $\geq 65$ years were excluded. Of 182 study patients 139 (76.4\%) were female and 43 (23.6\%) were male. None of the study subjects died within 30 days after PEG placement. No PEG-related mortality occurred during 3-month and 12-month follow-up.

In this study, 76 patients aged from 65 to 85 years were included in the Group 1 and 106 patients aged 86 years and over were included in the Group 2. 21 (11.2\%) patients developed either major or minor complications. 13 out of $76(\% 17.1)$ patients from the Group 1 and 8 out of 106 (7.5\%) patients from the Group 2 developed PEG-related complications. No statistically significant intergroup difference was observed in the rate of total complications associated with PEG $(p=0.06)$.

The most common complication was peristomal infection, which occurred in 11 patients. 7 out of these 11 patients were from the Group 1 and 4 patients were from the Group 2. No statistically significant difference was found between two groups in the incidence of peristomal infections $(p=0.206)$. The earliest peristomal infection occurred at day 7 postoperatively and the latest occurred at day 112 postoperatively and the mean time to the occurrence of infection was $27 \pm 31.1$ days. PEG tube feeding was discontinued in these patients, wound cultures were made and intravenous antimicrobial therapy was initiated. These patients were started on empirical antimicrobial therapy with ceftriaxone 1000 mg b.i.d and ornidazole 500 mg t.i.d given intravenously until susceptibility test results were available. Antimicrobial therapy regimens might be changed based on susceptibility test results. Antimicrobial therapy regimens might also be changed in refractory cases based on repeat wound cultures, if required. Ten of these 11 patients responded to treatment. Only one patient from the Group 2 experienced a treatment-refractory peristomal infection and underwent revision surgery.

Only one patient from the Group 1 developed gastrointestinal bleeding on the day of the PEG tube placement; PEG tube feeding was discontinued and the PEG tube was left in place for free drainage and this patient was started on proton pump inhibitor therapy. The bleeding stopped, and PEG tube feeding was resumed $48 \mathrm{~h}$ later.

Buried bumper syndrome (migration of the PEG tube from the stomach into the abdominal wall) was observed in two group1 patients. These two complications occurred 35 days and 120 days after the PEG tube placement, respectively and were corrected by revision surgery.

Formula leakage around the PEG tube site was observed in seven patients. 3 out of these 7 patients were from the Group 1 and 4 patients were from the Group 2. No statistically significant difference was found between two groups in the incidence of formula leakage around the PEG tube site $(p=1)$. The earliest formula leakage occurred at day 16 postoperatively and the latest occurred at day 154 postoperatively and the mean time to the occurrence of this complication was $73.5 \pm 49.9$ days. Thus, PEG tube feeding was discontinued and intravenous antimicrobial therapy was initiated with methylene blue through the PEG tube $72 \mathrm{~h}$ later. No formula leakage was observed after treatment 
in three of the seven patients, whereas leakage persisted in four. These four group 2 patients also underwent revision surgery due to persistent formula leakage from the PEG tube site. Thus, seven patients developed complications requiring PEG tube replacement.
Two patients from the Group 1 and 5 patients from the Group 2 underwent a PEG revision procedure. No statistically significant difference was found between two groups in the rates of patients who underwent revision surgery $(p=0.701)$ (Table 1).

Table 1. Percutaneous endoscopic gastrostomy tube complications and tube revision number of patients and rates in the Group 1 and Group 2.

\begin{tabular}{|l|r|r|r|}
\hline COMPLICATIONS & $\begin{array}{r}\text { Group 1 } \\
\mathbf{n = 7 6}\end{array}$ & $\begin{array}{r}\text { Group 2 } \\
\mathbf{n}=106\end{array}$ & $\mathbf{p}$ \\
\hline Peristomal infection & $7(9.2 \%)$ & $4(3.7 \%)$ & $\chi^{2}: 2.304 ; p=0.206$ \\
\hline Gastrointestinal bleeding & $1(1.3 \%)$ & - & $\chi^{2}: 1.402 ; p=0.418$ \\
\hline PEG tube feeding was discontinued & $3(3.9 \%)$ & $4(3.7 \%)$ & $\chi^{2}: 0.004 ; p=1$ \\
\hline The Buried Bumper Syndrome & $2(2.6 \%)$ & - & $\chi^{2}: 2.82 ; p=0.173$ \\
\hline Total complications & $13(17.1 \%)$ & $8(7.5 \%)$ & $\chi^{2}: 3.962 ; p=0.06$ \\
\hline PEG Revision & $2(2.6 \%)$ & $5(4.7 \%)$ & $\chi^{2}: 0.521 ; p=0.701$ \\
\hline
\end{tabular}

\section{DISCUSSION}

PEG is a common procedure indicated if enteral feeding is likely to be needed for a prolonged period of time in patients with a normal gastrointestinal function. However, the prevalence of chronic diseases is usually high among patients who require a PEG tube placement and these patients are usually in a poor health condition. Although standardized criteria have not been established yet, guidelines published by the American Gastroenterological Association recommend that PEG should be performed only in patients who are expected to survive for more than 30 days after the procedure. Despite ongoing efforts to determine risk factors for PEG-related complications and mortality, risk factors reported by several studies have been conflicting. In addition, although PEG has been shown to be a safer approach than percutaneous radiological and endoscopic surgical tube placement, complication rates associated with PEG have been reported to vary in a range between 13.2 and 42.9\% (10)

There are publications indicating associations between PEG placement and higher mortality rates and a reduced quality of life (11). On the contrary, reduced PEG-related mortality rates have been reported from studies in patients experiencing dysphagia as a result of amyotrophic lateral sclerosis or stroke (12). In a publication, Young et al. reported lower 30-day mortality rates in patients who underwent a PEG tube placement procedure due to dysphagia associated with neurological disorders, including Parkinson's disease and stroke (13). In our study, no death occured within 30 days after the procedure. No PEG-related mortality occurred during 3-month and 12-month follow-up. As stated above, we believe that these lower rates were associated with a careful patient selection before planning a PEG procedure. PEG tube placements were not performed patients in a 
poor health condition and in conditions which were expected to have a fatale course.

In another study, significant correlations were found between serious complications requiring a PEG tube change and mortality rates (13). Unlike this publication, no significant correlations were found between complications rates and mortality rates in this study.

In addition, several studies have investigated the safety of PEG. In a study of 314 patients, Larson et al. reported a minor complication rate of $33 \%$ and a major complication rate of $3 \%$. Major complications included gastric perforation, gastric bleeding and buried bumper syndrome (14). In our study, the rates of major and minor complications were $1.5 \%$ and $9.8 \%$, respectively. In addition, the rate of major complications was $2.6 \%$ in the Group 1 and $0 \%$ in the Group 2, while the rate of minor complications was $14.5 \%$ in the Group 1 and $7.5 \%$ in the Group 2. Major and minor complication rates detected in our study were found to be lower than those reported in the literature. Furthermore, no death occurred within 30 days after the procedures. We believe that these lower rates are associated with the compliance of our study patients with the eligibility criteria for PEG placement and clinical experience of the practitioners who performed the procedure. (AHG and FG have performed this procedure since 14 years ago). In another study of 161 elderly patients, peristomal infection was the most common complication (15). In line with the literature, peristomal infection was the most common complication in our study. The incidence of PEG complications can increase if PEG tube placement is not truly indicated or contraindicated (16). Although, there are studies reporting a positive correlation between complication rates and age (10), overall complication rate was $17.1 \%$ in the Group 1 and $7.5 \%$ in the Group 2 and the rate of complications was not statistically significantly higher in the group of patients aged 86 years and older, indicating that complication rates did not increase with age. In our study, 2 patients from the Group 1 and 5 patients from the Group 2 underwent a PEG revision procedure. No association was found between the age and the need for revision surgery in the group of geriatric patients.

Our literature search revealed another study analyzing complications by age, in a similar way to our study. This study used age of 100 years as the cutoff and the rate of minor complications was reported to be higher in those aged over the age of 100 years than the study subjects younger than 100 years of age. However, mortality and major complication rates in the group of patients aged 100 years and over were similar to the rates in the younger groups, in line with our study (17).

For most patients with dysphagia, PEG procedures are not performed on time typically because of the indecisiveness of relatives until the terminal stages of disease due to their prejudice and fear regarding PEG. Malnutrition and associated health problems are less common in patients who are fed through a PEG tube than in those patients who are not. Any delay in PEG tube insertion may harm patients who require feeding through a PEG tube. Practitioners should explain the procedure and benefits associated with the insertion of a PEG tube in detail to patients and their relatives to overcome their prejudice and fear regarding the procedure.

In conclusion, PEG appears to be associated with a low complication rate in geriatric patients when performed by experienced, accomplished practitioners. Our belief is further strengthened by the complication and revision rates which were not increased in the geriatric patient group in our study. We believe that more comprehensive preoperative assessments and preparations are needed before planning a PEG procedure in elderly patients aged 65 years and over.

\section{Conflict of interest}

None of the authors received any type of financial support that could be considered potential conflict of interest regarding the manuscript or its submission. 


\section{REFERENCES}

1. Cortez-Pinto H, Correia AP, Camilo ME, Tavares L, De Moura MC. Long-term management of percutaneous endoscopic gastrostomy by a nutritional support team. Clin Nutr 2002;21(1):27-31. (PMID:11884009).

2. Fortunato JE, Cuffari C. Outcomes of percutaneous endoscopic gastrostomy in children. Curr Gastroenterol Rep2011;13(3):293-9. (PMID:21409518).

3. Fröhlich $T$, Richter $M$, Carbon $R$, Barth $B$, Köhler $H$. Reviewarticle; percutaneous endoscopic gastrostomy in infants and children. Aliment Pharmacol Ther 2010;31(8):788-801. (PMID:20102353).

4. Gauderer MW, Ponsky JL, Izant RJ Jr. Gastrostomy without laparotomy; a percutaneous endoscopic technique. J Pediatr Surg 1980;15(6):872-5. (PMID:6780678).

5. Hiki N, Maetani I, Suzuki Y, et al. Reduced risk of peristomal infection of direct percutaneous endoscopic gastrostomy in cancer patients; comparison with the pull percutaneous endoscopic gastrostomy procedure. J Am Coll Surg 2008;207(5):737-44. (PMID:18954787).

6. Laasch HU, Wilbraham L, Bullen K, et al. Gastrostomy insertion; comparing the options- PEG, RIG or PIG ? Clin Radiol 2003;58(5):398-405. (PMID:12727170).

7. Larson DE, Burton DD, Schroeder KW, DiMagno EP. Percutaneous endoscopic gastrostomy. Indications, success, complications, and mortality in 314 consecutive patients. Gastroenterology 1987;93(1):48-52. (PMID:3108063).

8. Löser C, Aschl G, Hebuterne X, et al. ESPEN guidelines on artificial enteral nutrition percutaneous endoscopic gastrostomy (PEG). Clin Nutr 2005;24(5):848-61. (PMID:16261664).

9. Marik PE, Zaloga GP. Early enteral nutrition in acutely ill patients; a systematic review. Crit Care Med 2001;29(12):2264-70. (PMID:11801821).
10. Mendiratta P, Tilford JM, Prodhan P, et al. Trends in percutaneous endoscopic gastrostomy placement in the elderly from 1993 to 2003. Am J Alzheimers Dis Other Demen 2012;27(8):609-13. (PMID:23038714).

11. Pih GY, Na HK, Ahn JY, et al. Risk factors for complications and mortality of percutaneous endoscopic gastrostomy insertion. BMC Gastroenterol 2018;18(1):101. (PMID:29954339).

12. Raha SK, Woodhouse K. The use of percutaneous endoscopic gastrostomy (PEG) in 161 consecutive elderly patients. Age Ageing 1994;23(2):162-3. (PMID:8023728).

13. Sobani ZA, Tin K, Guttmann S, Abbasi AA, Mayer I, Tsirlin Y. Safety of percutaneous endoscopic gastrostomy tubes in centenarian patients. Clin Endosc 2018;51(1):56-60. (PMID:28728345).

14. Tham TC, Taitelbaum G, Carr-Locke DL. Percutaneous endoscopic gastrostomies; are they being done for the right reasons? OJM 1997;90(8):495-6. (PMID:9327026).

15. Toporowska-Kowalska E, Gębora-Kowalska B, Jabłoński J, Fendler W, Wąsowska-Królikowska K. Influence of percutaneous endoscopic gastrostomy on gastro-oesophageal reflux evaluated by multiple intraluminal impedance in children with neurological impairment. Dev Med Child Neurol. 2011;53(10):93843. (PMID:21752017).

16. Wirth R, Voss C, Smoliner C, et al. Complications and mortality after percutaneous endoscopic gastrostomy in geriatrics: a prospective multicenter observational trial. JAMDA 2012;13(3):228-33. (PMID:21872536).

17. Young $G$, Kyong $H$, Yong $J$, et al. Risk factors for complications and mortality of percutaneous endoscopic gastrostomy insertion. BMC Gastroenterology 2018;18(1):101. (PMID:29954339). 